\title{
Pore curvature and support composition effects on the electronic properties of supported Pt catalysts: An infrared spectroscopy study with $\mathrm{CO}$ as probe molecule
}

\author{
Muriel Lepage ${ }^{\mathrm{a}}$, Tom Visser ${ }^{\mathrm{b}}$, Ad M.J. van der Eerden ${ }^{\mathrm{b}}$, \\ Fouad Soulimani $^{\mathrm{b}}$, Bert M. Weckhuysen ${ }^{\mathrm{b}, *}$ \\ a Advanced Technology Division, Toyota Motor Europe, Hoge Wei 33B, B-1930 Zaventem, Belgium \\ ${ }^{\mathrm{b}}$ Inorganic Chemistry and Catalysis group, Department of Chemistry, Utrecht University, \\ Sorbonnelaan 16, 3584 CA Utrecht, The Netherlands \\ Received 5 July 2007; accepted 21 November 2007 \\ Available online 8 January 2008
}

\begin{abstract}
Supported $1 \mathrm{wt} \%$ Pt-based catalyst materials have been used as model systems to study pore curvature and support composition effects on the electronic properties of supported Pt nanoparticles. For this purpose, Pt nanoparticles have been loaded onto microporous (ITQ-1), mesoporous (SiMCM-41, Si-MCM-48 and Si-SBA-15), macroporous $\left(\mathrm{SiO}_{2}\right)$ all-silica supports, as well as onto a macroporous $\mathrm{SiO}_{2}$ support, impregnated with monovalent $\left(\mathrm{Na}^{+}, \mathrm{Cs}^{+}\right)$and divalent $\left(\mathrm{Mg}^{2+}, \mathrm{Ba}^{2+}\right)$ cations. Time- and temperature-dependent infrared spectroscopy with CO as probe molecule has been used to investigate the adsorption and desorption properties of $\mathrm{CO}$ from these supported Pt nanoparticles. At $350 \mathrm{~K}$, a narrow and smooth linear Pt-coordinated $\mathrm{C} \equiv \mathrm{O}$ vibration band at $2070 \mathrm{~cm}^{-1}$ was observed for the all-silica catalysts. The IR-CO-TPD results revealed a slightly higher desorption rate for the micro- and mesoporous supports, probably due to larger non-bonding electrostatic interactions between $\mathrm{CO}$ and the pore walls. A systematic shift from linear $(\mathrm{L})$ to bridge $(\mathrm{B})$ bonded $\mathrm{C} \equiv \mathrm{O}$ upon a decrease of the radius of curvature, which would indicate an increasing electron charge on the supported Pt nanoparticles, is however not observed. In contrast, a relationship between the L:B band intensity ratio and the Lewis acidity of the monovalent and divalent cations, as expressed by the Kamlet-Taft parameter $\alpha$, was observed for the Pt/SiO $\mathrm{O}_{2}$ catalysts. This effect is less pronounced than for zeolite-supported Pt nanoparticles (J. Phys. Chem. B 2005, 109, 3822-3831), but the results demonstrate that the correlation can be easily transferred from one support type to another, thus providing further guidelines for the design of improved automotive catalysts.
\end{abstract}

(C) 2007 Elsevier B.V. All rights reserved.

Keywords: Automotive catalysis; CO-oxidation; Support effect; Zeolites

\section{Introduction}

The catalytic properties of supported nano-sized noble metal particles are known to be tuneable by changing the chemical composition, porosity and structure of the support material. However, despite many characterization studies that have been undertaken to elucidate the exact nature of this metal-support effect [1-6], many questions still remain, preventing the design of improved catalyst systems based on an intelligent choice of the support material. In principle, three effects of the support on the

\footnotetext{
* Corresponding author.

E-mail address: b.m.weckhuysen@chem.uu.nl (B.M. Weckhuysen).
}

catalytic activity of the metal particles can be distinguished: i.e., (1) the support composition, (2) the support pore size and curvature and (3) the presence of promoting elements. In previous papers, we have reported on well-defined Pt nanoparticles supported on a microporous crystalline aluminosilicate material [7-9]. More specifically, we have investigated the effect of monovalent $\left(\mathrm{Na}^{+}, \mathrm{K}^{+}, \mathrm{Rb}^{+}\right.$and $\left.\mathrm{Cs}^{+}\right)$and divalent $\left(\mathrm{Mg}^{2+}, \mathrm{Ca}^{2+}\right.$, $\mathrm{Sr}^{2+}$ and $\left.\mathrm{Ba}^{2+}\right)$ cations on the electronic properties of $\mathrm{Pt}$ nanoparticles entrapped in the supercages of zeolite $\mathrm{Y}$. $\mathrm{Pt}-\mathrm{C} \equiv \mathrm{O}$ temperature programmed desorption infrared spectroscopy (TPD-IR) and atomic X-ray absorption fine structure (AXAFS) studies were used to determine the electron charge on the supported Pt nanoparticles. It was found that the Pt electron density increased with decreasing Lewis acidity of the cation 
introduced in the zeolite matrix. Simultaneously, the $\mathrm{CO}$ coverage increased with increasing electron density, which resulted in an enhanced $\mathrm{CO}$ oxidation activity.

In order to further shed light insight into the origin of these intriguing metal-support interactions, it is worthwhile to perform a similar systematic study on the effect of the support pore curvature. For that reason, we have decided to investigate the physicochemical properties of supported Pt nanoparticles in a series of catalysts with different curvatures of the support wall by means of CO IR-TPD spectroscopy. To exclude effects of the chemical composition, we have investigated a series of Ptloaded all-silica supports with an architecture ranging from micropores over mesopores to macropores. ITQ-1 is an allsilica microporous molecular sieve with a pore structure similar to that of zeolite Y [10-12], while Si-MCM-41, Si-MCM-48 and Si-SBA-15 are different mesoporous solids also possessing amorphous silica walls $[13,14]$. Finally, $\mathrm{SiO}_{2}$ is an amorphous all-silica material containing macropores. It will be shown that the effect of the pore curvature of an all-silica support on the electron density of supported Pt nanoparticles plays only a minor role. As a consequence, the chemical composition of the support must play the dominant role. For that reason, it was a logical next step to investigate whether the effect on the electronic properties of the metal particles that was obtained by the introduction of promoting cations in Pt/zeolite-Y [7-9], can be transferred to other support materials, such as an all-silica one. For this purpose, we have studied a series of $\mathrm{Pt} / \mathrm{SiO}_{2}$ catalysts loaded with monovalent $\left(\mathrm{Na}^{+}, \mathrm{Cs}^{+}\right)$and divalent $\left(\mathrm{Mg}^{2+}, \mathrm{Ba}^{2+}\right)$ cations. It will be shown that the promoting effect also correlates with the Lewis acidity of the cations under study, although the promoting effect is less pronounced than previously observed for zeolite-based materials.

\section{Experimental}

\subsection{Catalyst preparation}

The microporous silica material ITQ-1 has been synthesized according to a recipe of Camblor and co-workers [10-12]. SiSBA-15, Si-MCM-41 and Si-MCM-48 materials were used as mesoporous silica supports and were prepared according to the method of, respectively, Van der Voort et al. [13,14], Mokaya and Jones [15] and Baltes et al. [16]. Amorphous $\mathrm{SiO}_{2}$ was used as a macroporous support and obtained from Aldrich (Davisil $645)$. The same material was used to prepare $\mathrm{Na}-\mathrm{SiO}_{2}, \mathrm{Cs}-$ $\mathrm{SiO}_{2}, \mathrm{Mg}-\mathrm{SiO}_{2}$ and $\mathrm{Ba}-\mathrm{SiO}_{2}$ by dry impregnation with aqueous solutions of the corresponding metal nitrates. The following materials were used for this purpose: $\mathrm{NaNO}_{3}$ (Merck, p.a.), $\mathrm{CsNO}_{3}$ (Acros, 99.9\%), $\mathrm{Mg}\left(\mathrm{NO}_{3}\right)_{2} \cdot 6 \mathrm{H}_{2} \mathrm{O}$ (Acros, 99\%) and $\mathrm{Ba}\left(\mathrm{NO}_{3}\right)_{2}$ (Merck, p.a.).

Next, 1 wt\% supported Pt particles were prepared via a dry impregnation step of the support materials with the appropriate aqueous solutions of $\mathrm{Pt}\left(\mathrm{NH}_{3}\right)_{4}\left(\mathrm{NO}_{3}\right)_{2}$. After impregnation and drying at $353 \mathrm{~K}$ in $\mathrm{N}_{2}$ (quality 4.0; Hoekloos) for $8 \mathrm{~h}$, calcination was carried out by drying in a high air flow $(30 \mathrm{ml} /$ min) during $12 \mathrm{~h}$ followed by increasing the temperature to $573 \mathrm{~K}$ at a heating rate of $0.2 \mathrm{~K} / \mathrm{min}$, where it was kept for $8 \mathrm{~h}$ to achieve complete removal of $\mathrm{NH}_{3} / \mathrm{NO}_{3}$ prior to reduction. Reduction was performed in a $60 \mathrm{ml} / \mathrm{min} \mathrm{H}_{2}$ (quality 5.0; Hoekloos) flow with a ramp of $5 \mathrm{~K} / \mathrm{min}$ to $573 \mathrm{~K}(1 \mathrm{~h})$. After reduction and flushing with $\mathrm{N}_{2}$ at room temperature, passivation was carried out by increasing the $\mathrm{O}_{2}$ flow to $10 \mathrm{ml} / \mathrm{min}$ to prevent aggregation of $\mathrm{Pt}$ particles. The physicochemical properties of the different catalyst materials under study have been summarized in Table 1.

\subsection{Catalyst characterization}

X-ray fluorescence (XRF) was carried out on all samples to determine the Pt and cation loadings using a Spectro X-lab 2000 instrument (Spectro). $\mathrm{N}_{2}$ physisorption was performed at $77 \mathrm{~K}$ with a Micromeritics ASAP 2400 apparatus (quality 4.0; Hoekloos). Prior to these measurements, the samples were degassed for $24 \mathrm{~h}$ at $573 \mathrm{~K}$ in vacuum. Surface area, pore volume and pore size distribution were calculated with standard BET theory. High-resolution transmission electron microscopy (HRTEM) was done with a Philips CM 30 UT electron microscope equipped with a field emission gun as the source of electrons, operated at $300 \mathrm{kV}$. Samples were mounted on a microgrid carbon polymer supported on a copper grid by placing a few droplets of a suspension of ground sample in ethanol on the grid, followed by drying at ambient conditions. Extended X-ray absorption fine structure (EXAFS) measurements were carried out at the ESRF (Grenoble, France) at CRG

Table 1

Physico-chemical properties of the catalysts under study

\begin{tabular}{|c|c|c|c|c|c|c|}
\hline Sample & wt $\% \mathrm{Pt}$ & Particle size $(\mathrm{nm})$ & $\begin{array}{l}\text { Coordination } \\
\text { number }(\mathrm{N})\end{array}$ & Surface area $\left(\mathrm{m}^{2} / \mathrm{g}\right)$ & Pore volume $(\mathrm{ml} / \mathrm{g})$ & $\begin{array}{l}\text { Mean pore } \\
\text { diameter }(\mathrm{nm})\end{array}$ \\
\hline Pt/ITQ-1 & 1.4 & 1 & 6.5 & 418 & 0.18 & 3.2 \\
\hline Pt/MCM-41 & 0.7 & $1-4$ & 8.2 & 947 & 1.08 & 2.7 \\
\hline Pt/MCM-48 & 1.0 & $1-4$ & 7.6 & 690 & 1.15 & 3.0 \\
\hline $\mathrm{Pt} / \mathrm{SBA}-15$ & 0.7 & 1 & 6.5 & 678 & 0.90 (0.17 micro) & 5.8 \\
\hline $\mathrm{Pt} / \mathrm{SiO} 2$ & 0.9 & $1-4$ & 7.9 & 542 & 0.23 & 16 \\
\hline $\mathrm{Pt} / \mathrm{Na}-\mathrm{SiO}_{2}$ & 1.8 & $1-2$ & - & 125 & $<0.01$ & 12 \\
\hline $\mathrm{Pt} / \mathrm{Cs}-\mathrm{SiO}_{2}$ & 1.2 & $1-10$ & 8.8 & 102 & $<0.01$ & 26 \\
\hline $\mathrm{Pt} / \mathrm{Mg}-\mathrm{SiO}_{2}$ & 1.7 & $1-3$ & - & 209 & $<0.01$ & 7.5 \\
\hline $\mathrm{Pt} / \mathrm{Ba}-\mathrm{SiO}_{2}$ & 1.3 & $1-3$ & 7.0 & 193 & $<0.01$ & 18 \\
\hline
\end{tabular}

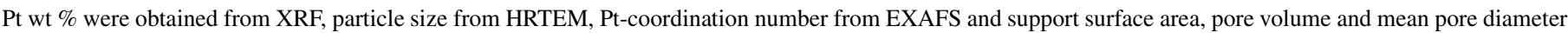
from $\mathrm{N}_{2}$ physisorption measurements. 
DUBBLE (BM26A). The samples were prepared by pressing 0.12 to $0.14 \mathrm{~g}$ powder to a self-supporting wafer. Next, the wafer was placed in a treatment cell. Prior to measurement, the sample was dried at $423 \mathrm{~K}$ for $30 \mathrm{~min}$ in a flow of dry $\mathrm{He}$ and then slowly heated to $573 \mathrm{~K}$ under a flow of $10 \% \mathrm{H}_{2}$ in $\mathrm{He}$ to reduce the passivated Pt. Finally, the samples were measured at liquid $\mathrm{N}_{2}$ temperature. EXAFS data analysis was carried out with the XDAP program [17].

Infrared (IR) measurements were performed on selfsupporting catalyst wafers that were pressed from 0.01 to $0.05 \mathrm{~g}$ of calcined and reduced sample material. A pressure of 3 bar was applied during $10 \mathrm{~s}$ to prevent destruction of the pore structure of the support [18]. The wafer was placed in an IR transmission cell equipped with $\mathrm{CaF}_{2}$ windows as previously described [19]. The cell was evacuated to $10^{-8}$ bar followed by drying of the wafer at $323 \mathrm{~K}$ overnight prior to reduction by a $10 \mathrm{ml} / \mathrm{min}$ flow of $\mathrm{H}_{2}$ (quality 4.6; Hoekloos). During reduction the temperature was raised from 323 to $573 \mathrm{~K}$ where it was maintained for $1 \mathrm{~h}$. Next, the system was switched to vacuum and after $1 \mathrm{~h}$ at $573 \mathrm{~K}$, cooled to $323 \mathrm{~K}$ at a rate of $3 \mathrm{~K} / \mathrm{min}$. In the next step, the catalyst wafer was exposed to $10 \% \mathrm{CO}$ (quality 4.7; Hoekloos) in He (quality 4.6; Hoekloos) at a pressure of 0.2 bar. After $30 \mathrm{~min}$ of static pressure, the system was re-evacuated and after another $30 \mathrm{~min}$, temperature programmed desorption (TPD) was started by increasing the temperature from 323 to $573 \mathrm{~K}(3 \mathrm{~K} / \mathrm{min})$, where it was maintained for $30 \mathrm{~min}$. IR spectra were recorded on a PerkinElmer 2000 FTIR instrument with a data point resolution of $4 \mathrm{~cm}^{-1}$. For each spectrum 25 scans were co-added. As a background, the spectrum of the catalyst wafer was taken after drying, reduction and cooling down to $323 \mathrm{~K}, 2$ min prior to $\mathrm{CO}$ exposure. During CO adsorption and TPD, time-resolved scanning was carried out by automatically acquiring spectral data every $2 \mathrm{~min}$, using Perkin-Elmer Time-Base software. Intensity data were acquired by calculating the integrated area of baseline corrected spectra using the Perkin-Elmer Spectrum software.

\section{Results and discussion}

\subsection{Catalyst characterization}

The physicochemical properties of the catalyst materials under study as obtained with $\mathrm{N}_{2}$ physisorption, XRF, HRTEM and EXAFS have been summarized in Table 1. The surface area of Pt/ITQ-1 was $418 \mathrm{~m}^{2} / \mathrm{g}$ with a mean pore diameter of $3.2 \mathrm{~nm}$ and a micropore volume of $0.18 \mathrm{ml} / \mathrm{g}$. The surface area of the mesoporous Pt/Si-MCM-41, Pt/Si-MCM-48 and Pt/Si-SBA-15 was 947,690 and $678 \mathrm{~m}^{2} / \mathrm{g}$, respectively. This is a reduction of about 10-20\% compared to the BET results obtained prior to $\mathrm{Pt}$ impregnation and is attributed to blocking of some of the pore architecture. The corresponding pore diameters were 2.7, 3.0 and $5.8 \mathrm{~nm}$. The results for Si-SBA-15 pointed to a significant amount of $1 \mathrm{~nm}$ micropores, next to the $5.8 \mathrm{~nm}$ mesopores $[13,14]$. The amorphous $\mathrm{SiO}_{2}$ samples exhibited the expected low pore volumes $(<0.1 \mathrm{ml} / \mathrm{g})$ and average mean pore diameters larger than $10 \mathrm{~nm}$. The Pt content of the different catalyst materials as determined by XRF varied between 0.7 $(\mathrm{Pt} / \mathrm{SBA}-15)$ and $1.7\left(\mathrm{Pt} / \mathrm{Mg}-\mathrm{SiO}_{2}\right)$ wt\% Pt. The estimated amount of cations in the $\mathrm{Pt} / \mathrm{Na}-\mathrm{SiO}_{2}$ and $\mathrm{Pt} / \mathrm{Mg}-\mathrm{SiO}_{2}$ samples was $0.5 \mathrm{wt} \%$, while for $\mathrm{Pt} / \mathrm{Cs}-\mathrm{SiO}_{2}$ and $\mathrm{Pt} / \mathrm{Ba}-\mathrm{SiO}_{2}$ a content of $4 \mathrm{wt} \%$ was determined with XRF. The HRTEM pictures revealed that the Pt nanoparticles of the all-silica catalysts are well dispersed. The majority of the particles were about $1 \mathrm{~nm}$ with some larger Pt-agglomerates for $\mathrm{Pt} / \mathrm{Si}-\mathrm{MCM}-41, \mathrm{Pt} / \mathrm{Si}$ MCM-48 and $\mathrm{Pt} / \mathrm{SiO}_{2}$. The metal ion-impregnated $\mathrm{Pt} / \mathrm{SiO}_{2}$ samples showed Pt clusters of 1-3 nm for Pt/Na-SiO, $\mathrm{Pt} / \mathrm{Mg}-$ $\mathrm{SiO}_{2}$ and $\mathrm{Pt} / \mathrm{Ba}-\mathrm{SiO}_{2}$, while for $\mathrm{Pt} / \mathrm{Cs}-\mathrm{SiO}_{2}$ particles up to $10 \mathrm{~nm}$ were present. The same observation of larger Pt particles was made previously on the Pt/Cs-Y catalysts [7-9]. To illustrate the Pt particle size and distribution, a selection of HRTEM micrographs of Pt/ITQ-1, Pt/Si-MCM-41, Pt/Na-SiO 2 and $\mathrm{Pt} / \mathrm{Ba}-\mathrm{SiO}_{2}$ is presented in Fig. 1 .

The Pt coordination numbers determined with EXAFS are in close agreement with the results of HRTEM. For Pt/ITQ-1 and $\mathrm{Pt} / \mathrm{Si}$-SBA-15, a coordination number of about 6.5 was found, which corresponds to an average Pt particle size of $1.1 \mathrm{~nm}$, while the values of 7-8 obtained for Pt/Si-MCM-41, Pt/SiMCM-48 and the $\mathrm{Pt} / \mathrm{SiO}_{2}$ samples point to an average diameter of about $1.5 \mathrm{~nm}$.

\subsection{Infrared $\mathrm{CO}$ adsorption experiments}

The results of the IR-CO temperature programmed desorption are shown in 3D projection in Figs. 2 and 3. The corresponding band maxima, the half band width (HBW) of the linear band and the linear-to-bridge (L:B) intensity ratio at selected temperatures are listed in Table 2 . All catalysts show a strong IR-absorption band in the range $2100-2000 \mathrm{~cm}^{-1}$ and a weaker one at around $1800 \mathrm{~cm}^{-1}$. The high wavenumber band is commonly assigned to the linear Pt-bonded $\mathrm{C} \equiv \mathrm{O}$ stretching vibration, while the lower frequency components are attributed to bridge coordinated types of $\mathrm{CO}[7-9,19-24]$. At higher temperature the band patterns becomes more complex due to reorientation of the $\mathrm{CO}$ as result of changing interactions [7$9,24]$. In what follows, we will discuss the effects of the pore curvature and the promoting elements separately.

\subsubsection{Pore curvature effects}

In order to study the effect of the pore curvature of the support material on the electronic properties of the supported $\mathrm{Pt}$ nanoparticles, the IR-CO-TPD results of the all-silica microporous (Pt/ITQ-1), mesoporous (Pt/Si-MCM-41, Pt/Si-MCM48 and $\mathrm{Pt} / \mathrm{Si}-\mathrm{SBA}-15)$ and macroporous $\left(\mathrm{Pt} / \mathrm{SiO}_{2}\right)$ catalysts have been compared. The linear coordinated CO stretching band is smooth and fairly symmetrical for all compounds. Besides, as listed in Table 2, the $\mathrm{HBW}$ at $323 \mathrm{~K}$ is rather small $\left(28-37 \mathrm{~cm}^{-1}\right)$, which points to a single type of linear coordinated $\mathrm{C} \equiv \mathrm{O}$ and hence to a more or less uniform $\mathrm{Pt}$ particle size. This is in line with the results from HRTEM and EXAFS.

At low temperature, the band around $1800 \mathrm{~cm}^{-1}$ is also virtually symmetrical, which suggests mainly one type of bridge-bonded $\mathrm{CO}$. At these conditions, the integrated band 

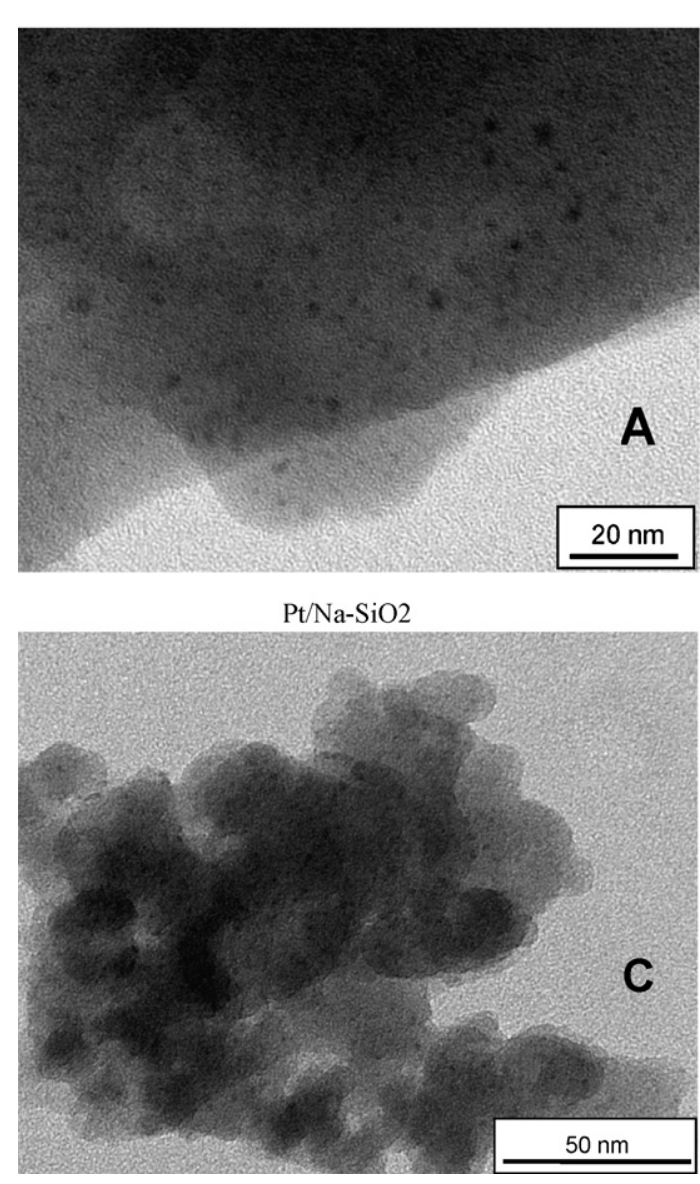

Fig. 1. HRTEM micrographs of Pt/ITQ-1 (A), Pt/Si-MCM-41 (B), Pt/Na-SiO 2 (C) and Pt/Ba-SiO 2 (D).

intensity is less then $10 \%$ of that of the linear coordinated band (i.e. L:B ratio $>10$, Table 2 ) for all catalyst materials, indicating a limited presence of bridged conformations. Furthermore, above $423 \mathrm{~K}$, an absorption band at around $1940 \mathrm{~cm}^{-1}$ grows in, pointing to the formation of bridge-bonded $\mathrm{CO}$. At identical conditions, the position of the linear $\mathrm{C} \equiv \mathrm{O}$ band at $323 \mathrm{~K}$ is practically the same for all catalyst materials and the shift to lower wavenumber upon increasing the temperature is small (17-23 $\left.\mathrm{cm}^{-1}\right)$. Cooling down to ambient temperature after TPD resulted in a small blue shift of the $\mathrm{C} \equiv \mathrm{O}$ band, but different from what has been reported for $\mathrm{Pt} / \mathrm{SiO}_{2}$ by Barth and Ramachandran [23], a gain in intensity was not observed. According to the literature [20], frequency shifts of 20$30 \mathrm{~cm}^{-1}$ can be largely attributed to changes in temperature and for that reason we conclude that the effect of the pore curvature on the $\mathrm{C} \equiv \mathrm{O}$ stretching vibration is small. Hence, assuming that the $\mathrm{C} \equiv \mathrm{O}$ force constant is inversely proportional to the $\mathrm{Pt}-$ $\mathrm{C}(\mathrm{O})$ bond strength, one would expect that the $\mathrm{CO}$ desorption shows the same picture for all catalyst materials. However, as can be seen from Fig. 2, the IR-desorption patterns are not identical. The main difference is observed in the decrease of the linear band above $523 \mathrm{~K}$. As will be shown later, this is not only caused by $\mathrm{CO}$ desorption, but also partly by the conversion of linear into bridge bonded CO conformations, as expressed by the small increase in intensity of the band at $1800 \mathrm{~cm}^{-1}$. The reduction in intensity of the linear $\mathrm{CO}$ band follows the order
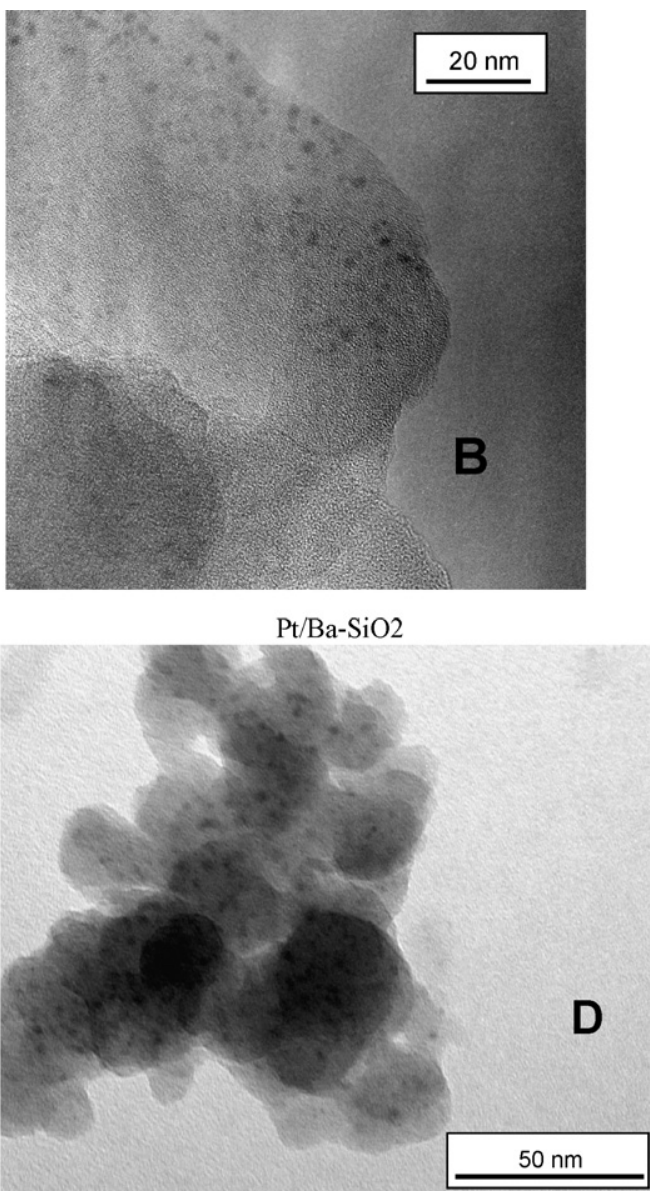

Pt/Si-MCM-41 > Pt/Si-MCM-48 Pt/Si-SBA-15 > Pt/SiO 2 , which is the inverse ranking of the corresponding mean pore diameter (Table 1), although the Pt/ITQ-1 material seems not to follow this trend. In principle, two non-bonding effects might play a role here. The first one is Coulomb interaction between $\mathrm{CO}$ and framework oxygen atoms. Regarding the small pore diameter of particularly, Pt/Si-MCM-41, Pt/Si-MCM-48 and $\mathrm{Pt} / \mathrm{ITQ}-1$ in relation to the $1 \mathrm{~nm}$ Pt particle size, it is plausible to assume that such an electrostatic interaction will play the largest role in the microporous and mesoporous supports. Since these interactions are repulsive, it explains the higher desorption rate for the smaller pore diameter supports. Indeed, one could argue that the small pore volume of ITQ-1 should have been attended with a larger effect, but this can be explained by assuming the Pt nanoparticles to be partly present outside the micropores. The second effect is the increasing contact area of the Pt particles and the support when the pore curvature increases, as schematically visualized in Fig. 4.

In this model, a larger contact area will result in a larger electron withdrawing influence of the acidic support sites on the Pt nanoparticles. As a consequence, the back donation to $\mathrm{CO}$ decreases and the $\mathrm{Pt}-\mathrm{C}(\mathrm{O})$ bond strength becomes weaker, which results in a higher $\mathrm{CO}$ desorption rate as observed. According to the literature, a decrease in back donation might also cause a reduced presence of bridge bonded $\mathrm{Pt}-\mathrm{C} \equiv \mathrm{O}$ [3,7-9], but, as can be seen from Table 2 , the linear to bridge intensity ratio $(\mathrm{L}: \mathrm{B})$ is 

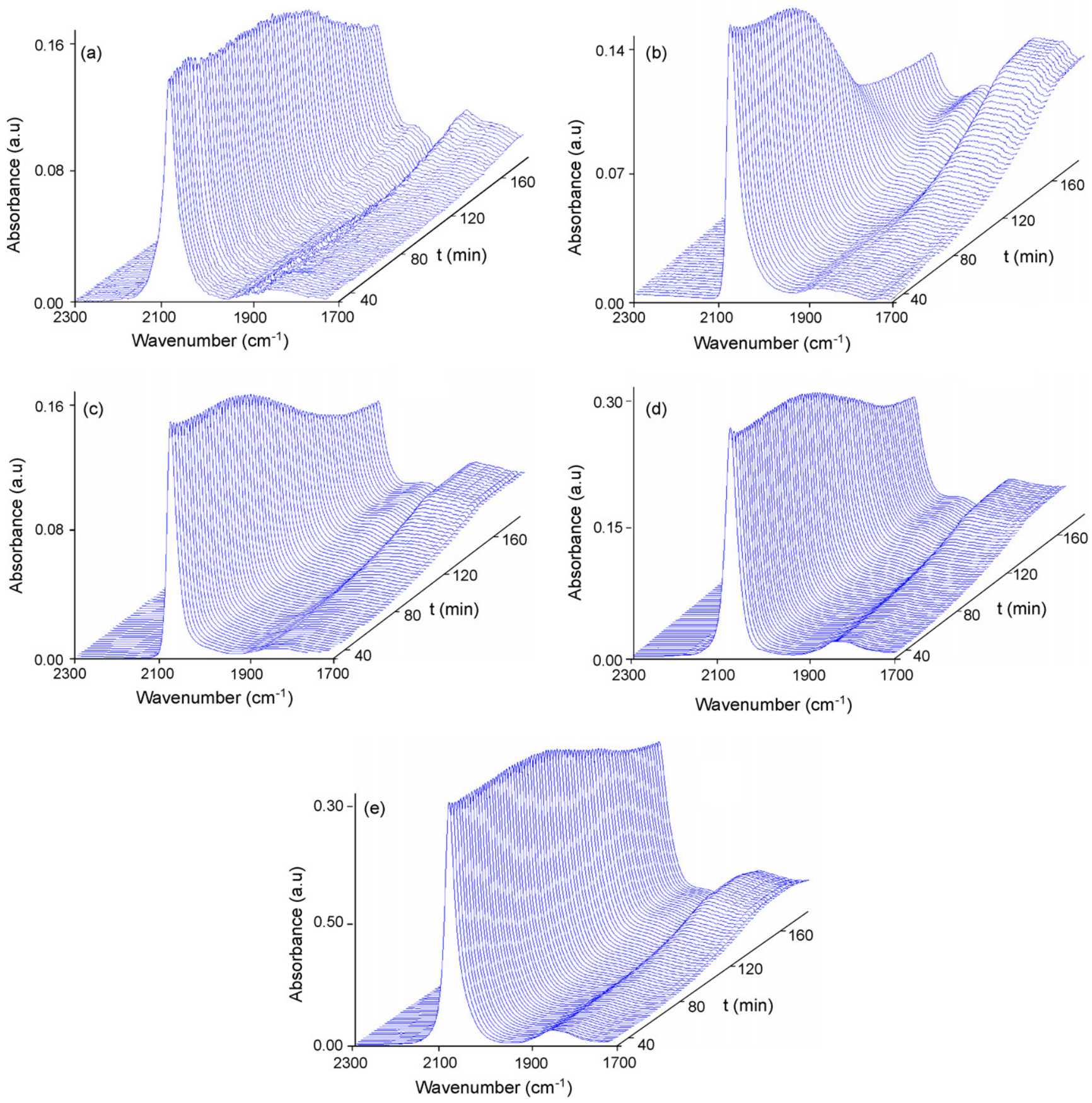

Fig. 2. Time-resolved IR spectra during temperature programmed $\mathrm{CO}$ desorption from Pt/ITQ-1, Pt/Si-MCM-41, Pt/Si-MCM-48, Pt/Si-SBA-15 and Pt/SiO 2 .

about the same for all catalyst materials. In principle, a decreased back donation to $\mathrm{CO}$ and repulsive $\mathrm{O} \cdots \mathrm{O}$ interactions might lead to a higher $\mathrm{C} \equiv \mathrm{O}$ frequency, but as already concluded such correlation is absent. It confirms the conclusion from our earlier studies on Pt/zeolite- $\mathrm{Y}$ catalysts, that a high $\mathrm{C} \equiv \mathrm{O}$ stretching frequency is not by definition related to a weak $\mathrm{Pt}-\mathrm{C}(\mathrm{O})$ bonding and vice versa [7-9]. This is also in accordance with the conclusion of Wasileski et al. [25], that there is no simple correlation between the field dependent Pt-bonded $\mathrm{C} \equiv \mathrm{O}$ vibration frequency and the $\mathrm{Pt}-\mathrm{C}(\mathrm{O})$ bonding energy.

Next, we calculated the surface coverage of the different catalyst materials as a function of the desorption temperature from the integrated intensities of all bands, according to the procedure described before [7]. The result is shown in Fig. 5.

Consistent with the TPD patterns in Fig. 2, all catalysts show a decrease in coverage at higher temperature, but the effect is smaller. This is due to the fact that the intensity decrease observed for the linear band in the TPD pattern (Fig. 2) is partly compensated by the conversion of linear to bridge-bonded CO. According to our conclusions from the study on zeolitesupported Pt nanoparticles [7-9], one could expect the relatively high coverage on $\mathrm{Pt} / \mathrm{SiO}_{2}$ to be attended with a smaller $\mathrm{L}: \mathrm{B}$ ratio and a lower linear $(\mathrm{Pt}-) \mathrm{C} \equiv \mathrm{O}$ stretching frequency, but this is not the case. It implies that, next to cation-induced changes of the 

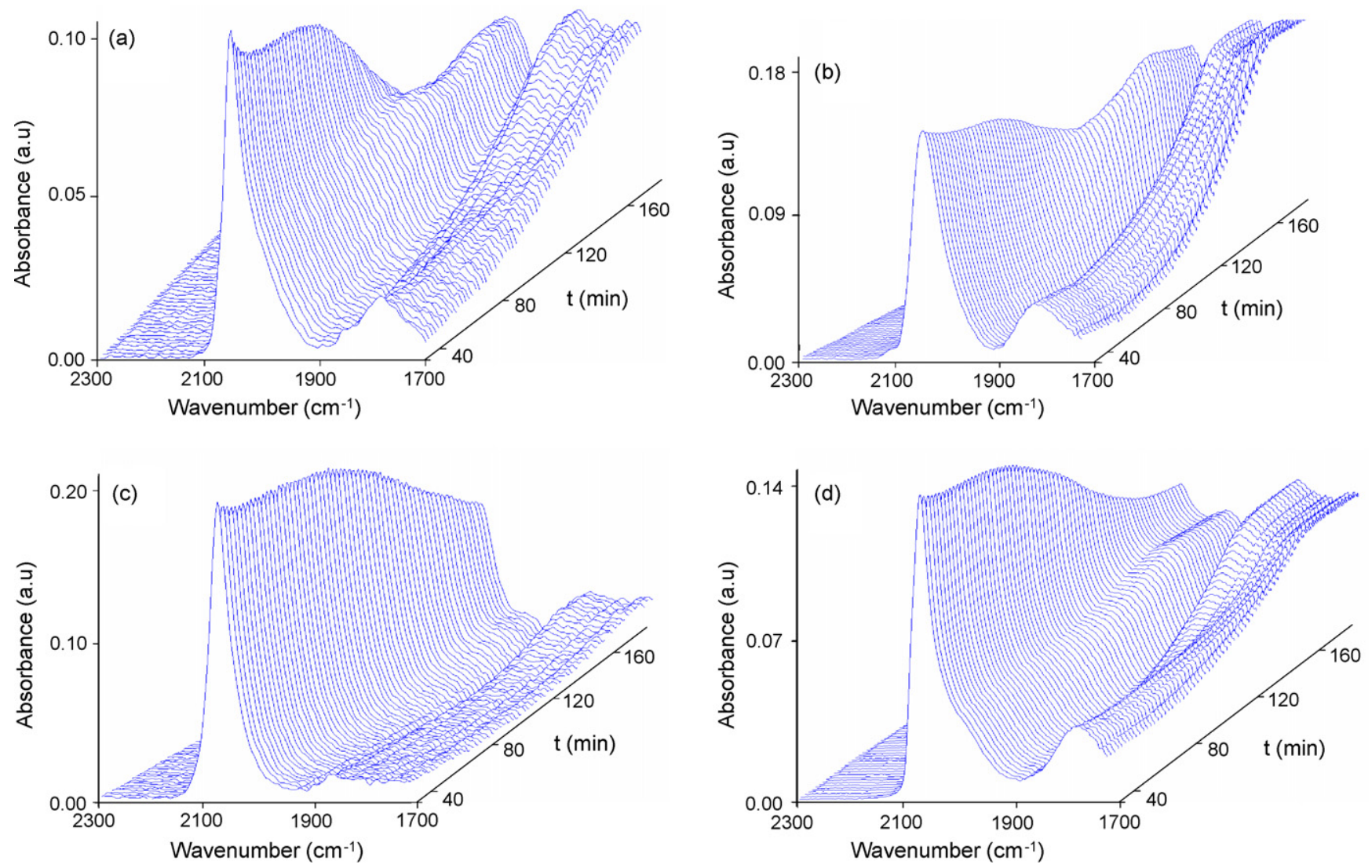

Fig. 3. Time-resolved IR spectra during temperature programmed $\mathrm{CO}$ desorption from $\mathrm{Pt} / \mathrm{Na}-\mathrm{SiO}_{2}, \mathrm{Pt} / \mathrm{Cs}-\mathrm{SiO}_{2}, \mathrm{Pt} / \mathrm{Mg}-\mathrm{SiO} \mathrm{O}_{2}$ and $\mathrm{Pt} / \mathrm{Ba}-\mathrm{SiO}{ }_{2}$.

electronic charge on the Pt particles, another effect plays a role in the CO adsorption capacity of supported Pt particles. Apparently, this effect is also not directly linked to the pore curvature of the support.

\subsubsection{Chemical composition effects}

In order to study chemical composition effects on the electronic properties of supported $\mathrm{Pt}$ nanoparticles, IR-COTPD patterns of cation-containing $\mathrm{Pt} / \mathrm{M}-\mathrm{SiO}_{2}$ catalysts $(\mathrm{Pt} / \mathrm{Na}-$ $\mathrm{SiO}_{2}, \mathrm{Pt} / \mathrm{Cs}-\mathrm{SiO}_{2}, \mathrm{Pt} / \mathrm{Mg}-\mathrm{SiO}_{2}$ and $\mathrm{Pt} / \mathrm{Ba}-\mathrm{SiO}_{2}$ ) have been measured, together with the reference $\mathrm{Pt} / \mathrm{SiO}_{2}$ material. The results have been compared to the data previously reported for the corresponding zeolite-supported Pt nanoparticles, i.e., Pt/
$\mathrm{H}-\mathrm{Y}, \mathrm{Pt} / \mathrm{Na}-\mathrm{Y}, \mathrm{Pt} / \mathrm{Cs}-\mathrm{Y}, \mathrm{Pt} / \mathrm{Mg}-\mathrm{Y}$ and $\mathrm{Pt} / \mathrm{Ba}-\mathrm{Y}$ [7-9]. As it appeared, the IR-CO-TPD results of both series of samples show a striking resemblance. Alike the $\mathrm{Pt} / \mathrm{M}-\mathrm{Y}$ catalysts, upon introduction of a cation, the $\mathrm{Pt} / \mathrm{M}-\mathrm{SiO}_{2}$ materials exhibit much broader and irregularly shaped bands (Fig. 3). This is illustrated by the HBW of $53-83 \mathrm{~cm}^{-1}$ at $323 \mathrm{~K}$, which is considerably larger than the HBW of $29 \mathrm{~cm}^{-1}$ as observed for $\mathrm{Pt} / \mathrm{SiO}_{2}$ (Table 2). One explanation could be the presence of different $\mathrm{CO}-\mathrm{Pt}$ adsorption sites. However, this is unlikely, since the HRTEM and EXAFS results show that, except for Pt/Cs- $\mathrm{SiO}_{2}$, the average Pt particle size and distribution is about the same for $\mathrm{Pt} / \mathrm{SiO}_{2}, \mathrm{Pt} / \mathrm{Na}-\mathrm{SiO}_{2}, \mathrm{Pt} / \mathrm{Mg}-\mathrm{SiO}_{2}$ and $\mathrm{Pt} / \mathrm{Ba}-\mathrm{SiO}_{2}(1-$ $3 \mathrm{~nm}$ ). For that reason we assign the observed band broadening

Table 2

Maxima $\left(\mathrm{cm}^{-1}\right)$ of the linear and bridge coordinated $\mathrm{C} \equiv \mathrm{O}$ stretching bands at different temperatures during TPD

\begin{tabular}{|c|c|c|c|c|c|c|c|c|c|c|c|c|}
\hline \multirow[t]{2}{*}{ Sample } & \multirow{2}{*}{$\begin{array}{l}\text { HBW } \\
323 \mathrm{~K}\end{array}$} & \multirow{2}{*}{$\begin{array}{l}\text { L:B } \\
323 \mathrm{~K}\end{array}$} & \multicolumn{6}{|c|}{ Linear $\mathrm{Pt}-\mathrm{C} \equiv \mathrm{O}$ band at } & \multicolumn{4}{|c|}{ Bridged $\mathrm{Pt}-\mathrm{C} \equiv \mathrm{O}$ band at } \\
\hline & & & $323 \mathrm{~K}$ & $373 \mathrm{~K}$ & $473 \mathrm{~K}$ & $573 \mathrm{~K}$ & $473 \mathrm{~K}$ & $573 \mathrm{~K}$ & $323 \mathrm{~K}$ & $373 \mathrm{~K}$ & $473 \mathrm{~K}$ & $573 \mathrm{~K}$ \\
\hline Pt/ITQ-1 & 37 & 10.3 & 2071 & 2069 & 2060 & 2050 & 1950 & 1950 & 1829 & 1820 & 1839 & 1832 \\
\hline $\mathrm{Pt} / \mathrm{MCM}-48$ & 28 & 11.5 & 2070 & 2069 & 2061 & 2053 & 1940 & 1937 & 1816 & 1819 & 1829 & 1830 \\
\hline Pt/SBA-15 & 29 & 12.4 & 2069 & 2068 & 2060 & 2046 & 1936 & 1936 & 1826 & 1825 & 1825 & 1828 \\
\hline $\mathrm{Pt} / \mathrm{SiO} 2$ & 29 & 11.1 & 2070 & 2069 & 2063 & 2052 & 1940 & 1939 & 1833 & 1820 & 1818 & 1818 \\
\hline $\mathrm{Pt} / \mathrm{Mg}-\mathrm{SiO} 2$ & 54 & 8.9 & 2066 & 2065 & 2058 & 2041 & 1940 & 1941 & 1815 & 1815 & 1815 & 1816 \\
\hline $\mathrm{Pt} / \mathrm{Ba}-\mathrm{SiO} 2$ & 53 & 4.4 & 2064 & 2063 & 2054 & 2046 & 1950 & 1936 & 1763 & 1765 & 1816 & 1819 \\
\hline
\end{tabular}

Half band width $\left(\mathrm{HBW}, \mathrm{cm}^{-1}\right.$ ) of the linear Pt-CO band and linear to bridge (L:B) intensity ratio at $323 \mathrm{~K}$. 


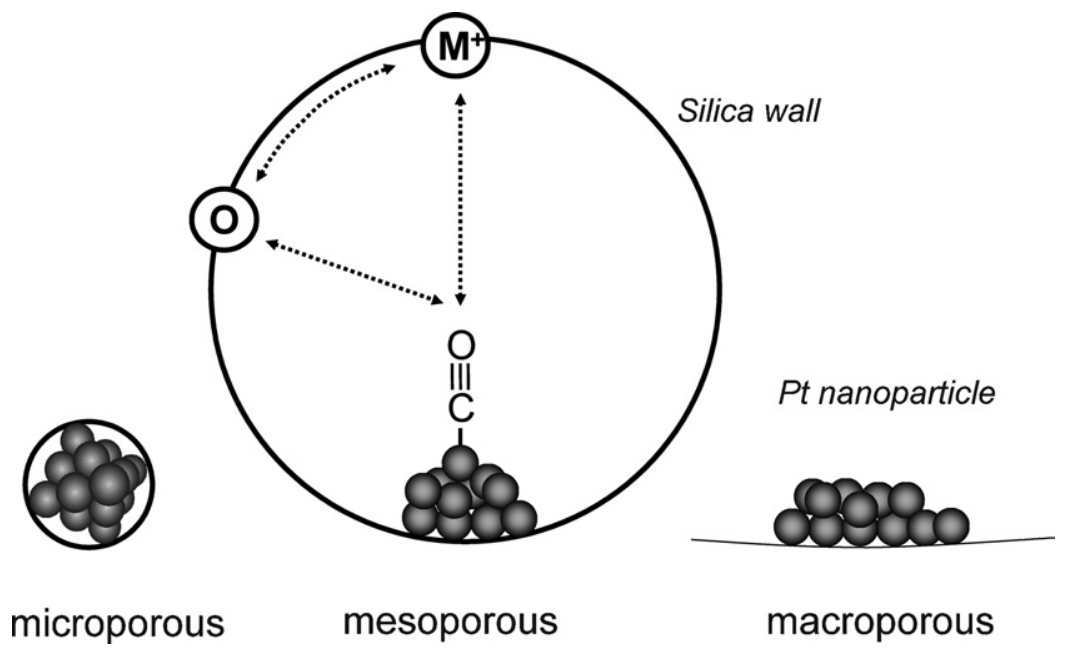

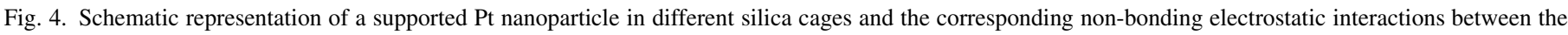

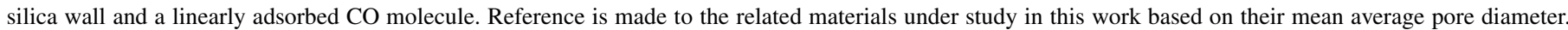

to different $\mathrm{C} \equiv \mathrm{O}$ orientations as a result of local non-bonding electrostatic interactions within the support. As outlined in our previous work on promotion effects in $\mathrm{Pt} / \mathrm{M}-\mathrm{Y}$ catalyst systems [7-9], attractive ion-dipole interactions with charge compensating framework cations play a major role in this process. It also explains the larger complexity of the $\mathrm{Pt}-\mathrm{C} \equiv \mathrm{O}$ bands as a result of the presence of both cation-affected and "free" $\mathrm{C} \equiv \mathrm{O}$ positions. Besides, the increasing band complexity at higher temperature can be attributed to reorientation of $\mathrm{C} \equiv \mathrm{O}$ as a result of changing interactions. Identical to the $\mathrm{Pt} / \mathrm{M}-\mathrm{Y}$ catalysts, this phenomenon is particularly visible in the IRCO-TPD pattern of $\mathrm{Pt} / \mathrm{Na}-\mathrm{SiO}_{2}, \mathrm{Pt} / \mathrm{Cs}-\mathrm{SiO}_{2}$ and $\mathrm{Pt} / \mathrm{Ba}-\mathrm{SiO}_{2}$ from the increasing intensity of the band at $1950 \mathrm{~cm}^{-1}$. This band has been tentatively assigned by Gandao et al. [24] to bridge-bonded $\mathrm{Pt}-\mathrm{CO}$ species affected by $\left(\mathrm{Mg}^{2+}\right)$ cations in the near vicinity of the supported $\mathrm{Pt}$ particles.

The positions of the $\mathrm{Pt}-\mathrm{C} \equiv \mathrm{O}$ vibration bands during TPD are listed in Table 2. Again, alike for the Pt/M-Y catalyst systems, the linear $\mathrm{C} \equiv \mathrm{O}$ band position decreases upon introduction of the metal cations in the same order as their

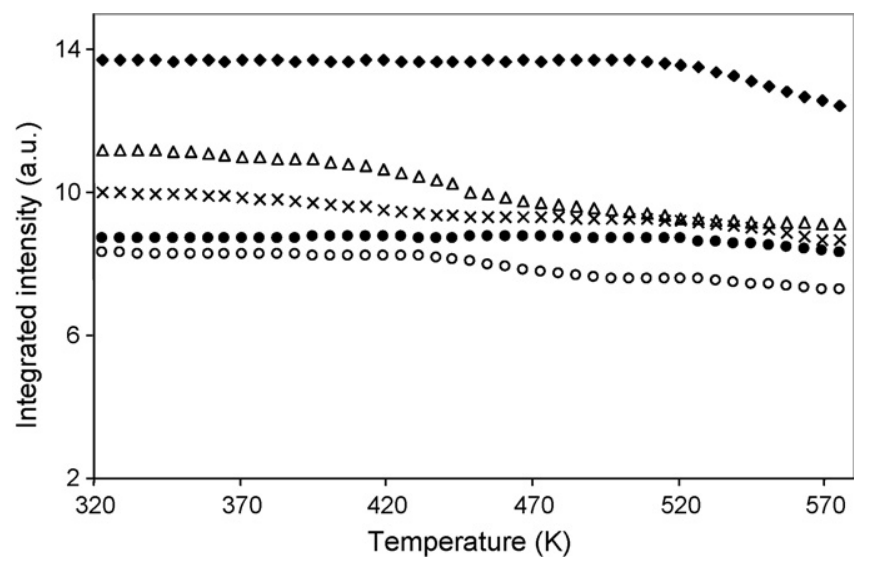

Fig. 5. CO coverage on all-silica supported Pt nanoparticles as a function of the

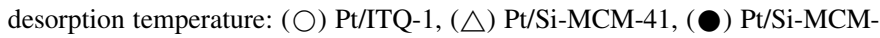
48, (x) Pt/Si-SBA-15 and $(\diamond) \mathrm{Pt} / \mathrm{SiO}_{2}$. position in the periodic system, i.e., $\mathrm{Na}>\mathrm{Cs}$ and $\mathrm{Mg}>\mathrm{Ba}$. Besides, the red shifts show the same trend as for the Pt/M-Y samples [7-9]. Once more, this points to a correlation between the $\mathrm{Pt} / \mathrm{C} \equiv \mathrm{O}$ vibrational frequency and the electronic properties of the supported Pt nanoparticles as induced by the mono-valent and di-valent cations. This is illustrated by the plot of the red shift of the linearly Pt-coordinated $\mathrm{C} \equiv \mathrm{O}$ bands compared to gas-phase $\mathrm{C} \equiv \mathrm{O}$ (positioned at $2143 \mathrm{~cm}^{-1}$ ) versus the cation radius-to-charge ratio of the four different elements [26,27] in Fig. 6. Evidently, the Pt/M-SiO 2 samples show the same trend as the previously reported $\mathrm{Pt} / \mathrm{M}-\mathrm{Y}$ catalysts, confirming the correlation of a high red shift with a large cation radius-to-charge ratio. Similar conclusions can be drawn for the effect of the cations on the IR linear to bridge (L:B) intensity ratio. Alike the $\mathrm{Pt} / \mathrm{M}-\mathrm{Y}$ compounds, the L:B values of the $\mathrm{Pt} / \mathrm{M}-\mathrm{SiO}_{2}$ catalysts at $323 \mathrm{~K}(3.6-8.9)$ are lower than the $\mathrm{L}: \mathrm{B}$ value of $\mathrm{Pt} / \mathrm{SiO}_{2}$ (11.1). Plotting of the $\mathrm{L}: \mathrm{B}$ intensity ratio as a function of the Lewis acidity of the cations, as shown in Fig. 7, reveals exactly the same trend as reported for the $\mathrm{Pt} / \mathrm{M}-\mathrm{Y}$ samples.

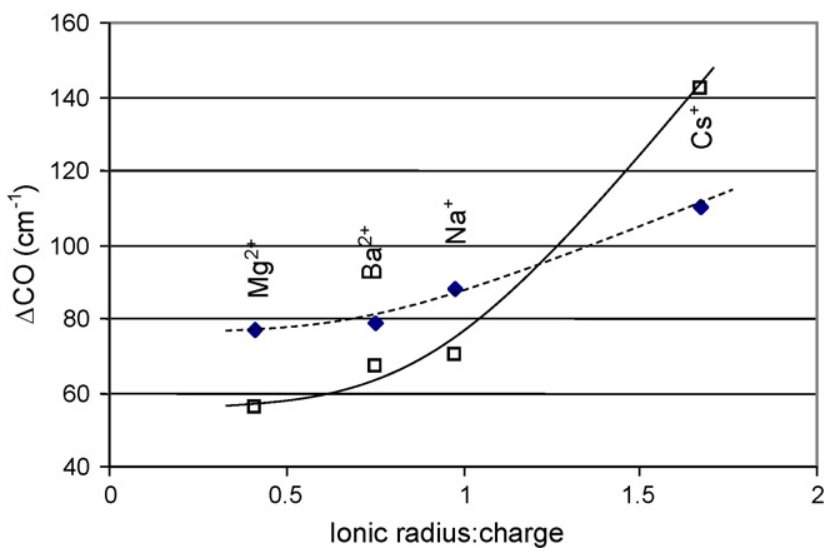

Fig. 6. Red shift of the $\mathrm{C} \equiv \mathrm{O}$ stretching vibration of linearly bond $\mathrm{CO}$ on cation impregnated $\mathrm{Pt} / \mathrm{M}-\mathrm{SiO}_{2}(\diamond)$ and $\mathrm{Pt} / \mathrm{M}-\mathrm{Y}(\square)$ catalysts compared to the gas phase $\mathrm{C} \equiv \mathrm{O}$ frequency as a function of the cation radius-to-charge ratio. 


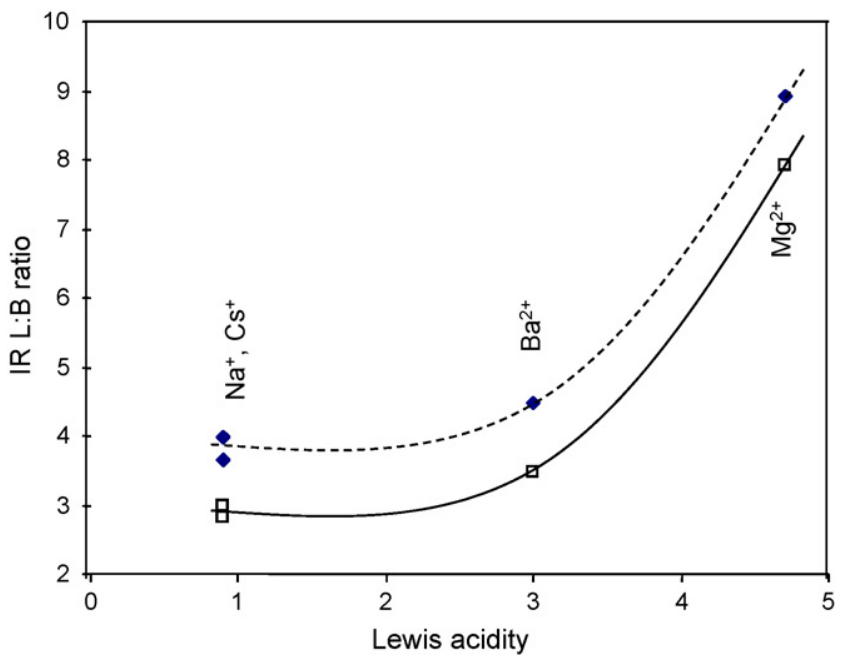

Fig. 7. Relation between IR L:B intensity ratio and Lewis acidity of the cations $\mathrm{Na}^{+}, \mathrm{Cs}^{+}, \mathrm{Mg}^{2+}$ and $\mathrm{Ba}^{2+}$ impregnated onto the $\mathrm{SiO}_{2}(\diamond)$ and zeolite- $\mathrm{Y}(\square)$ support as expressed by the Kamlet Taft parameter $\alpha$.

As explained previously [7], the Kamlet-Taft parameter $\alpha$ is a measure for the Lewis acidity of the cations and reflects the ability of a cation to accept an electron pair. Therefore, weak Lewis acid elements, such as $\mathrm{Na}^{+}$and $\mathrm{Cs}^{+}$, have a small $\alpha$-value and induce a relatively large electron charge on the framework oxygen atoms and hence on the supported Pt nanoparticles. For these elements, the net result is an increasing occupation of the d-levels, an increasing back donation in the $\mathrm{CO}$ molecular orbital with $2 \pi^{*}$ character and eventually an increasing red shift of the linear $\mathrm{C} \equiv \mathrm{O}$ band and a decreasing infrared $\mathrm{L}: \mathrm{B}$ ratio. Obviously, the effect of an element with a high $\alpha$-value, such as $\mathrm{Mg}^{2+}$, is much smaller and in line with the results of an IR-CO adsorption study on the promoting effect of manganese in titania-supported cobalt Fischer-Tropsch catalysts [28].

Finally, we calculated the CO surface coverage of the Pt/M$\mathrm{SiO}_{2}$ catalysts from the integrated $\mathrm{C} \equiv \mathrm{O}$ band intensities as a function of the desorption temperature. The results are shown in Fig. 8.

As appears, the $\mathrm{CO}$ coverage (i.e. the summed integrated area of all $\mathrm{CO}$ bands) decreases only slightly with the

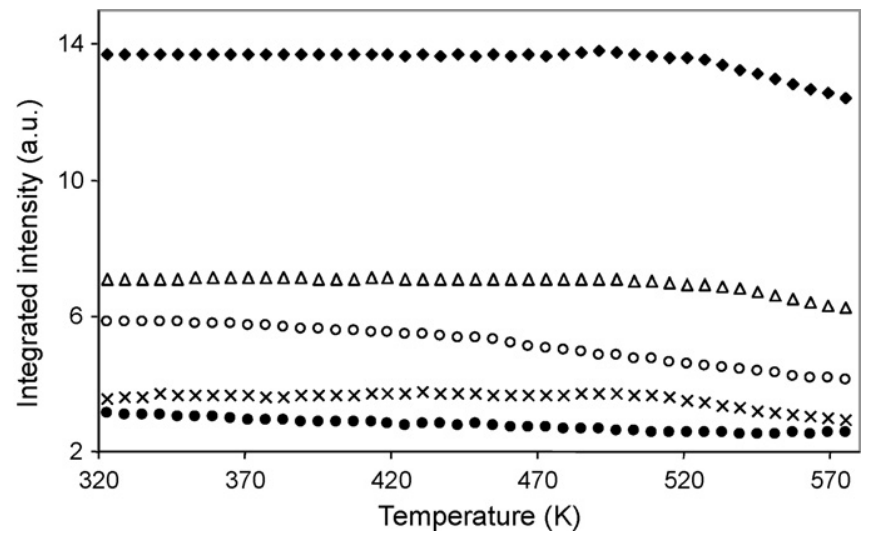

Fig. 8. CO coverage on supported $\mathrm{Pt}$ nanoparticles as a function of the desorption temperature: $(\diamond) \mathrm{Pt} / \mathrm{SiO}_{2},(\bullet) \mathrm{Pt} / \mathrm{Na}-\mathrm{SiO}_{2},(\times) \mathrm{Pt} / \mathrm{Cs}-\mathrm{SiO}_{2},(\triangle)$ $\mathrm{Pt} / \mathrm{Mg}-\mathrm{SiO}_{2}$ and (O) $\mathrm{Pt} / \mathrm{Ba}-\mathrm{SiO}_{2}$. temperature and less than suggested by the 3D TPD patterns in Fig. 3. It follows that desorption is minimal and that the linear bonded $\mathrm{CO}$ converts to the two and threefold coordinated form. Furthermore, the relative amount of adsorbed $\mathrm{CO}$ is the highest on $\mathrm{Pt} / \mathrm{Mg}-\mathrm{SiO}_{2}$ and the lowest on $\mathrm{Pt} / \mathrm{Na}-\mathrm{SiO}_{2}$ and $\mathrm{Pt} / \mathrm{Cs}-\mathrm{SiO}_{2}$ with the value for $\mathrm{Pt} / \mathrm{Ba}-\mathrm{SiO}_{2}$ in between. It is clear that, even though the coverage for $\mathrm{Pt} / \mathrm{Cs}-\mathrm{SiO}_{2}$ is probably relatively too low, due to the larger Pt nanoparticles and hence a smaller Ptsurface area, the $\mathrm{CO}$ coverage correlates inversely proportional with the L:B ratio and the red shift of the linear Pt-CO band (Table 2). These results are identical to what we observed for the Pt/M-Y compounds and confirm the earlier conclusion that promoting elements can be used to affect the electron density of supported Pt particles.

\section{Conclusions}

The results of this characterization study demonstrate that time-resolved IR spectroscopy is a useful tool to study temperature programmed desorption effects of $\mathrm{CO}$ as probe molecule to unravel electronic properties of supported $\mathrm{Pt}$ nanoparticles. The new data largely confirm the conclusions from our previous study on promotion effects in zeolitesupported Pt nanoparticles that IR parameters, like the CO surface coverage and the position, shape and relative intensity of the linear and bridge Pt-bonded $\mathrm{C} \equiv \mathrm{O}$ stretching vibration, can be used to determine the electronic properties of supported $\mathrm{Pt}$ nanoparticles. It is concluded that pore curvature effects are very small. The band positions, shifts and L:B ratio differ hardly, although desorption seems to decrease with the mean pore diameter due to repulsive non-bonding interactions and/or the larger contact area between the Pt particles and the support. The results for the cation-containing $\mathrm{Pt} / \mathrm{M}-\mathrm{SiO}_{2}$ catalysts are consistent with the results, previously obtained for zeolitesupported Pt nanoparticles. The red shift of the linear Ptcoordinated $\mathrm{C} \equiv \mathrm{O}$ vibration compared to that of gas-phase $\mathrm{CO}$ increases with an increasing cation radius-to-charge ratio, while a decrease in the L:B ratio correlates with a decreasing Lewis acidity, as expressed by the Kamlet-Taft parameter $\alpha$. Although principally different, both observations can be attributed to an increasing electron charge on the framework oxygen atoms and hence to an increasing electron density on the supported Pt nanoparticles upon decreasing $\alpha$-value. Furthermore, the correlation of the $\mathrm{CO}$ coverage with the electron density on $\mathrm{Pt}$ is present though less prominent as for zeolite-supported Pt nanoparticles.

\section{Acknowledgments}

This work has been funded by Toyota Motor Europe. We kindly thank fruitful discussions with Prof. Matsumoto (Toyota Motor Corporation, Japan), Dr. Ikeda (Material Engineering Division, Toyota Motor Europe, Belgium) and Prof. Koningsberger (Utrecht University, the Netherlands). We are also indebted to Prof. Van der Voort (Gent University, Belgium) for assistance in preparing the Si-MCM-41, Si-MCM-48 and SiSBA-15 materials, Prof. Garcia (Universidad Politecnica de 
Valencia, Spain) for providing us with the ITQ-1 material, Dr. Beale (Utrecht University, the Netherlands) for help with the EXAFS analysis and Mr. Mens (Utrecht University, the Netherlands) for carrying out the $\mathrm{N}_{2}$ sorption measurements. The authors also acknowledge beam time grants from the DUBBLE Grenoble beam line station.

\section{References}

[1] L.M. Kustov, D. Ostgard, W.M.H. Sachtler, Catal. Lett. 9 (1991) 121.

[2] J.T. Miller, D.C. Koningsberger, J. Catal. 162 (1996) 209.

[3] D.C. Koningsberger, D.E. Ramaker, J.T. Miller, J. de Graaf, B.L. Mojet, Top. Catal. 15 (2001) 35.

[4] G.E. Arena, G. Centi, Top. Catal. 30/31 (2004) 147.

[5] I. Sobczak, J. Grams, M. Ziolek, Micropor. Mesopor. Mater. 99 (2007) 345.

[6] A.Y. Stakheev, Y. Zhang, A.V. Ivanov, G.N. Baeva, D.E. Ramaker, D.C. Koningsberger, J. Phys. Chem. C 111 (2007) 3938.

[7] T. Visser, T.A. Nijhuis, A.M.J. van der Eerden, K. Jenken, Y. Ji, W. Bras, S. Nikitenko, Y. Ikeda, M. Lepage, B.M. Weckhuysen, J. Phys. Chem. B 109 (2005) 3822.

[8] A.M.J. van der Eerden, T. Visser, T.A. Nijhuis, Y. Ikeda, M. Lepage, D.C. Koningsberger, B.M. Weckhuysen, J. Am. Chem. Soc. 127 (2005) 3272.

[9] T. Visser, T.A. Nijhuis, A.M.J. van der Eerden, K. Jenken, Y. Ji, Y. Ikeda, M. Lepage, B.M. Weckhuysen, Stud. Surf. Sci. Catal. 158 (2005) 1239.

[10] M.A. Camblor, C. Corell, A. Corma, M.J. Diaz-Cabanas, S. Nicolopoulos, J.M. Gonzalez-Calbet, M. Vallet-Regi, Chem. Mater. 8 (1996) 2415.

[11] A. Corma, C.R.A. Catlow, G. Sastre, J. Phys. Chem. B 102 (1998) 7085.
[12] M.A. Camblor, A. Corma, M.J. Diaz-Cabanas, C. Baerlocher, J. Phys. Chem. B 102 (1998) 44.

[13] P. Van Der Voort, P.I. Ravikovittch, K.P. de Jong, M. Benjelloun, E. Van Bavel, A.H. Janssen, A.V. Neimark, B.M. Weckhuysen, E.F. Vansant, J. Phys. Chem. B 106 (2002) 5873.

[14] P. Van Der Voort, P.I. Ravikovitch, K.P. de Jong, A.V. Neimark, A.H. Janssen, M. Benjelloun, E. van Bavel, P. Cool, B.M. Weckhuysen, E.F. Vansant, Chem. Commun. (2002) 1010.

[15] R. Mokaya, W. Jones, Chem. Commun. (1997) 2185.

[16] M. Baltes, K. Cassiers, P. Van der Voort, B.M. Weckhuysen, R.A. Schoonheydt, E.F. Vansant, J. Catal. 197 (2001) 160.

[17] M. Vaarkamp, J.C. Linders, D.C. Koningsberger, Physica B 208/209 (1995) 9825

[18] E. Geidel, H. Lechert, J. Dobler, H. Jobic, G. Calazferri, F. Bauer, F. Micropor, Mesopor. Mater. 65 (2003) 31.

[19] M. Vaarkamp, B.L. Mojet, M.J. Kappers, J.T. Miller, D.C. Koningsberger, J. Phys. Chem. 99 (1995) 16067.

[20] N. Sheppard, T.T. Nguyen, Adv. Infrared Raman Spectrosc. 5 (1978) 67.

[21] C. Hippe, R. Lamber, G. Schulz-Ekloff, U. Schubert, Catal. Lett. 43 (1997) 195.

[22] A. Bourane, D. Bianchi, J. Catal. 218 (2003) 447.

[23] A. Barth, A. Ramachandran, J. Catal. 125 (1990) 467.

[24] Z. Gandao, B. Coq, L.C. de Ménorval, D. Tichit, Appl. Catal. A: Gen. 147 (1996) 395.

[25] S.A. Wasileski, M.A. Weaver, M.T.M. Koper, J. Electroanal. Chem. 500 (2001) 344.

[26] N.N. Greenwood, N.N. Earnshaw, A Chemistry of the Elements, Pergamon Press, Oxford, 1984.

[27] Y. Marcus, Ion Properties, Marcel Dekker, New York, 1997, p. 193.

[28] F. Morales, E. de Smit, F.M.F. de Groot, T. Visser, B.M. Weckhuysen, J. Catal. 246 (2007) 91. 